\title{
Quality by Design Based Optimization of a High Performance Liquid Chromatography Method for Assay Determination of Low Concentration Preservatives in Complex Nasal Formulations
}

\author{
Jure Zakrajšek, ${ }^{1, *}$ Vladimir Stojić, ${ }^{1}$ Simona Bohanec ${ }^{1}$ and Uroš Urleb ${ }^{1}$ \\ ${ }^{1}$ Lek Pharmaceuticals d.d., Verovškova 57, 1526 Ljubljana, Slovenia \\ * Corresponding author: E-mail: jure.zakrajsek@ sandoz.com \\ Tel.: +386158026 30, Fax.: +38615681393
}

Received: 09-06-2014

\begin{abstract}
The effects of seven different chromatographic parameters and five sample preparation parameters in a high performance liquid chromatography (HPLC) method for assay determination of benzalkonium chloride (BKC) in a nasal formulation were evaluated using two fractional factorial experimental designs. The design space of the analytical method was modeled using Umetrics Modde software and the optimal method conditions were predicted. The optimum HPLC chromatographic conditions were obtained using a Luna $\mathrm{CN}$ column $(150 \times 4.6 \mathrm{~mm}, 3 \mu \mathrm{m})$. The results show that mobile phase $\mathrm{pH}$, amount of acetonitrile in the mobile phase and column temperature are the most important factors in obtaining good separation of BKC homologs from an interfering peak. In the sample preparation step, the use of an aqueous solution for dissolving the samples was the most important factor since it eliminated the interfering effect of the active compound. The optimal method was validated for linearity, accuracy and precision.

The use of experimental designs enables obtaining the maximum amount of information with the least possible number of experiments. Such designs are an economical manner in evaluating a variety of different factors and their interactions.
\end{abstract}

Keywords: Quality by design; Fractional factorial design; Experimental design; HPLC method optimization; preservatives

\section{Introduction}

Quality by design has recently been adopted for the development of pharmaceutical products to ensure better product quality. ${ }^{1,2}$ The use of different experimental designs for evaluation of different factors and their interactions in compatibility studies of drug substance and other excipients has been described in the literature. Employing such an approach, the authors obtained the maximum amount of information with the smallest possible number of experiments. ${ }^{3}$ Fractional factorial design was also used to evaluate different process and formulation parameters in order to produce a more chemically stable and robust final drug product with lower initial levels of different impurities. $^{4}$

In recent years, efforts for applying the Quality by Design (QbD) concept to analytical method development have increased in order to achieve better control strategy of production processes. ${ }^{5,6,7}$ Although the QbD concept has not been fully adopted for the development of analytical methods, recent publications indicate the possibility of applying QbD principles to method development in order to determine the method operational design region and to achieve more robust analytical methods. ${ }^{8}$ Such a concept is required in order to ensure reliable measurements for each critical quality attribute (CQA) defined for a pharmaceutical product.

The proposed concept is based on the predefined requirements for an analytical method stated in the analytical target profile (ATP). During the development phase it is necessary to demonstrate that an analytical method meets the requirements predefined in the ATP. ${ }^{9,10}$ Design of experiments (DoE) should be used to assess the multidimensional combination and interactions of different factors that could have an influence on measurements. ${ }^{11}$ Different experimental designs, which have been reported 
in the literature, can be used for screening of the influence of different HPLC chromatographic parameters such as mobile phase $\mathrm{pH}$ value, percentage of organic modifier, column temperature and others. ${ }^{12,13,14}$ The use of experimental designs for optimization of water determinations employing the Karl Fisher titration analytical method is also described in literature. ${ }^{15}$

Benzalkonium chloride (BKC) is one of a number of preservatives used in pharmaceutical formulations. It is the preservative of choice for multiuse aqueous nasal, ophthalmic and otic products and has been in use since 1935. Numerous in vivo and in vitro studies demonstrated that no toxic effects were associated with BKC after both short- and long-term exposure to it in concentrations between $0.00045 \%$ and $0.1 \%{ }^{16}$

BKC solutions are effective against a wide range of bacteria, yeasts and fungi; therefore, it is widely used in pharmaceutical formulations as an antimicrobial preservative. It is used in ophthalmic preparations in concentrations ranging from $0.01 \%-0.02 \%$ and in nasal and otic formulations in concentrations ranging from $0.002-0.02 \%$. It is also used as a preservative in small-volume parenteral formulations and cosmetic preparations. ${ }^{17}$ It is a quaternary ammonium compound, a mixture of alkylbenzyldimethylammonium chloride with the molecular formula $\left[\mathrm{C}_{6} \mathrm{H}_{5} \mathrm{CH}_{2} \mathrm{~N}\left(\mathrm{CH}_{3}\right)_{2} \mathrm{R}\right] \mathrm{Cl}$, where $\mathrm{R}$ can be an alkyl group ranging from $\mathrm{n}-\mathrm{C}_{8} \mathrm{H}_{17}$ to $\mathrm{n}-\mathrm{C}_{18} \mathrm{H}_{37}$ (Figure 1). ${ }^{17}$

Quantitative determination of the amount of BKC homologs present in pharmaceutical formulations is necessary because of its antimicrobial potency and its influence on human health.

As BKC is a mixture of different homologs and is used in pharmaceutical formulations in low concentrations, it can be difficult to obtain reliable analytical measurements. In the past different HPLC ${ }^{18-21}$ and electrophoretic ${ }^{22,23}$ methods have been developed and used for qualitative and quantitative determination of BKC homologs.

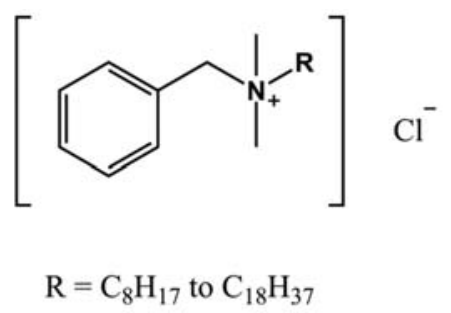

Figure 1. Structural formula of benzalkonium chloride. ${ }^{24}$

These methods are mainly used for determination of BKC in aqueous solutions of ophthalmic and nasal preparations. However, they were not suitable for determination of $\mathrm{BKC}$ in nasal suspension formulations due to interference of the active compound and other excipients. Therefore, an in-house method was developed for assay determination of Benzalkonium chloride (BKC) in nasal spray formulations.
The use of fractional factorial designs for optimization of the chromatographic conditions and the sample preparation step of a HPLC method for assay determination of BKC in aqueous solutions and in a suspension for intranasal application is demonstrated in the following article. The goal of the optimization was to improve the accuracy and precision of the assay method by achieving better chromatographic separation of BKC homologs from interfering chromatographic peaks of the active compound and other excipients.

\section{Experimental}

\section{1. Chemicals and Reagents}

Triethylamine $\left(\left(\mathrm{C}_{2} \mathrm{H}_{5}\right)_{3} \mathrm{~N}\right)$ (TEA), anhydrous sodium acetate $\left(\mathrm{CH}_{3} \mathrm{COONa}\right)$, anhydrous acetic acid $\left(\mathrm{CH}_{3} \mathrm{COOH}\right)$ and ortho-phosphoric acid $85 \%\left(\mathrm{H}_{3} \mathrm{PO}_{4}\right)$ were purchased from Merck KGaA (Darmstadt, Germany) and acetonitrile $\left(\mathrm{CH}_{3} \mathrm{CN}\right)(\mathrm{ACN})$ from J.T. Baker (Avantor Performance Materials, Center Valley, PA). All reagents used for preparation of solvents and mobile phases were of analytical grade. All aqueous solutions were prepared using highly purified water obtained from a Milli-Q water purification system (Millipore Corp., Bedford, MA). Benzalkonium chloride $(\geq 95.0 \%)$ was used as a reference standard and was purchased from Sigma-Aldrich (St. Louis, MO).

\section{2. Equipment}

All experiments were performed on a Waters Alliance 2695 Separations module equipped with a quaternary gradient pump, a temperature controlled column heater, an auto-sampler and Waters 2487 Dual absorbance detector (Waters Corporation, Milford, MA). Instrument control, data acquisition and processing of results were performed using Empower 3 chromatography Software (Waters Corporation, Milford, MA).

Optimization experiments were performed with a Luna $\mathrm{CN}$ analytical column $(150 \mathrm{~mm} \times 4.6 \mathrm{~mm}$ I.D., $3 \mu \mathrm{m})$ provided by Phenomenex (Torrance, CA).

Millipore Millex-HV Hydrophilic PVDF $0.45 \mathrm{~mm}$ disk filters, purchased from Millipore (Billerica, MA), were used to filter the final sample solutions before the analysis with the HPLC method.

All $\mathrm{pH}$ measurements of the mobile phase were carried out with a Mettler-Toledo SevenMulti $\mathrm{pH}$ meter using a Mettler-Toledo InLab Expert Pro pH electrode (Mettler-Toledo LLC, Columbus, OH). Umetrics MODDE 9.1 software (Umetrics AB, Umeå, Sweden) was used for developing experimental designs and evaluation and modeling of results.

\section{3. Analytical Method}

A fast gradient HPLC analytical method was initially developed to determine the assay of benzalkonium 
Table 1. Chromatographic conditions of the initial HPLC method for assay determination of BKC.

\begin{tabular}{|c|c|c|c|}
\hline Mobile phase A & \multicolumn{3}{|c|}{$15 \mathrm{mM}$ sodium acetate buffer : Acetonitrile $:$ triethylamine $=850: 150: 5(\mathrm{v} / \mathrm{v} / \mathrm{v}), \mathrm{pH} 5.5$} \\
\hline Mobile phase B & \multicolumn{3}{|c|}{$15 \mathrm{mM}$ sodium acetate buffer : Acetonitrile : triethylamine $=500: 500: 5(\mathrm{v} / \mathrm{v} / \mathrm{v}), \mathrm{pH} 5.5$} \\
\hline Column & \multicolumn{3}{|c|}{ Phenomenex LUNA CN, $3 \mu \mathrm{m}, 100 \AA$, $150 \times 4.6 \mathrm{~mm}$} \\
\hline Column temperature & \multicolumn{3}{|c|}{$40^{\circ} \mathrm{C}$} \\
\hline Flow rate & \multicolumn{3}{|l|}{$1.5 \mathrm{~mL} / \mathrm{min}$} \\
\hline Detection wavelength & \multicolumn{3}{|l|}{$254 \mathrm{~nm}$} \\
\hline & Time $(\min )$ & $\% \mathrm{~A}$ & $\% \mathrm{~B}$ \\
\hline \multirow{4}{*}{ Gradient parameters } & 0 & 20 & 80 \\
\hline & 2 & 0 & 100 \\
\hline & 10 & 0 & 100 \\
\hline & 11 & 20 & 80 \\
\hline
\end{tabular}

chloride in nasal spray suspension samples. The initial chromatographic conditions are summarized in Table 1.

The method was not robust and the obtained results exhibited a high variability. Therefore, we optimized the sample preparation step and the chromatographic conditions of the method with two DoE fractional factorial designs. The goal of the optimization was to gain a more robust analytical method with less variability in the results, separation of all interfering placebo peaks and BKC homologs and improved resolution between the active compound and $\mathrm{BKC}$ homologs.

\section{4. Standard Solutions}

The benzalkonium chloride stock standard solution $(1.5 \mathrm{mg} / \mathrm{mL})$ was prepared by dissolving an appropriate amount of reference standard in acetonitrile. The working concentrations of BKC standard, in range 15-120 $\mu \mathrm{g} / \mathrm{mL}$, were obtained with further dilution of the stock standard solution. The sum of BKC homologs peak area was plotted against the corresponding concentration to obtain a calibration curve.

\section{5. Analysis of Samples}

To determine the assay of benzalkonium chloride in nasal suspension samples containing 0.05 to $0.2 \mathrm{mg} / \mathrm{g}$ of benzalkonium chloride, $5 \mathrm{~g}$ of suspension sample was accurately weighed and transferred to a $25 \mathrm{~mL}$ volumetric flask. About $20 \mathrm{~mL}$ of acetonitrile and $40 \mu \mathrm{L}$ of orthophosphoric acid were added and the solution sonicated for 15 minutes. Acetonitrile was added to the final volume and the solution left until the sediment had settled. The supernatant was filtered into HPLC vials using a Millipore Millex-HV Hydrophilic PVDF $0.45 \mu \mathrm{m}$ filter and analyzed with the initial method.

\section{Results and Discussion}

\section{1. HPLC Method Optimization}

Firstly, the chromatographic conditions of the initial analytical method were optimized by screening the influence of seven different chromatographic factors. A randomized two dimensional fractional factorial design $\left(2^{7-3}\right)$ with Resolution IV was used. In this design the three-factor interactions were replaced with new factors. This means that no factors are confounded with two-factor interactions, but each two-factor interaction is confounded with two other two-factor interactions.

The parameters tested were the amount of acetonitrile and triethylamine in mobile phases A and B, the mobile phase $\mathrm{pH}$ value, the percentage of mobile phase $\mathrm{A}$ at the start of the gradient, the first time point of the gradient,

Table 2. Factors and corresponding levels for $2^{7-3}$ fractional factorial design.

\begin{tabular}{|c|c|c|c|c|c|}
\hline Factor name & Abbr. & Settings & Level - & Level + & Level 0 \\
\hline (f1) Buffer pH & $\mathrm{pH}$ & 5.0 to 6.0 & 5.0 & 6.0 & 5.5 \\
\hline $\begin{array}{l}\text { (f2) Amount of TEA } \\
\text { in Mobile phase }\end{array}$ & TEA & 4 to $6 \mathrm{~mL}$ & $4 \mathrm{~mL}$ & $6 \mathrm{~mL}$ & $5 \mathrm{~mL}$ \\
\hline (f3) Amount of ACN & $\mathrm{ACN}$ & $\begin{array}{l}-25 \text { to }+25 \mathrm{~mL} \\
\text { with respect }\end{array}$ & $\begin{array}{c}\mathrm{H}_{2} \mathrm{O}: \mathrm{ACN} \\
\text { MPA: } 875: 125\end{array}$ & $\begin{array}{c}\mathrm{H}_{2} \mathrm{O}: \mathrm{ACN} \\
\text { MPA: } 825: 175\end{array}$ & $\begin{array}{c}\mathrm{H}_{2} \mathrm{O}: \mathrm{ACN} \\
\text { MPA: } 850: 150\end{array}$ \\
\hline in Mobile phase & & $\begin{array}{c}\text { to the initial composition } \\
\text { of MP }\end{array}$ & MPB: $525: 475$ & MPB: $475: 525$ & MPB: $500: 500$ \\
\hline (f4) Start \% Mobile phase A & $\% \mathrm{MPA}$ & 10 to $30 \%$ & $10 \%$ & $30 \%$ & $20 \%$ \\
\hline (f5) Gradient time point & Time & 1.5 to $2.5 \mathrm{~min}$ & $1.5 \mathrm{~min}$ & $2.5 \mathrm{~min}$ & $2.0 \mathrm{~min}$ \\
\hline (f6) Mobile phase flow rate & Flow & 1.3 to $1.7 \mathrm{~mL} / \mathrm{min}$ & $1.3 \mathrm{~mL} / \mathrm{min}$ & $1.7 \mathrm{~mL} / \mathrm{min}$ & $1.5 \mathrm{~mL} / \mathrm{min}$ \\
\hline (f7) Column temperature & Temp & 35 to $45^{\circ} \mathrm{C}$ & $35^{\circ} \mathrm{C}$ & $45^{\circ} \mathrm{C}$ & $40^{\circ} \mathrm{C}$ \\
\hline
\end{tabular}


Table 3. Randomized $2^{7-3}$ fractional factorial design and results of observed responses.

\begin{tabular}{|c|c|c|c|c|c|c|c|c|c|c|c|c|c|c|}
\hline \multirow{2}{*}{$\begin{array}{l}\text { Exp } \\
\text { No } \\
\end{array}$} & \multirow{2}{*}{$\begin{array}{c}\text { Run } \\
\text { Order }\end{array}$} & \multicolumn{7}{|c|}{ Factors } & \multicolumn{6}{|c|}{ Responses } \\
\hline & & f1 & f2 & $\mathbf{f 3}$ & f4 & f5 & f6 & f7 & $\mathbf{k}_{\mathrm{C12}}^{\prime}$ & $\mathbf{T}_{\mathrm{C} 12}$ & $\mathbf{R s}_{\mathbf{P}, \mathrm{C} 12}$ & $\mathbf{R s}_{\mathrm{A}, \mathrm{C} 12}$ & $\mathbf{R s}_{\mathrm{C12,C14}}$ & $\mathbf{R s}_{\mathrm{C14,C16}}$ \\
\hline$\overline{\mathrm{N} 11}$ & 1 & - & + & - & + & + & - & + & 2.76 & 1.16 & 1.140 & 4.64 & 3.97 & 4.21 \\
\hline N19 & 2 & 0 & 0 & 0 & 0 & 0 & 0 & 0 & 2.97 & 1.16 & 0.178 & 6.38 & 3.85 & 4.23 \\
\hline $\mathrm{N} 2$ & 3 & + & - & - & - & + & - & + & 3.82 & 1.16 & -1.082 & 9.20 & 4.49 & 4.65 \\
\hline N13 & 4 & - & - & + & + & + & - & - & 2.72 & 1.16 & 0.170 & 5.97 & 3.50 & 3.65 \\
\hline N3 & 5 & - & + & - & - & + & + & - & 2.67 & 1.08 & 0.977 & 4.92 & 3.55 & 3.94 \\
\hline N12 & 6 & + & + & - & + & - & - & - & 3.84 & 1.12 & -0.257 & 10.19 & 5.29 & 5.56 \\
\hline N1 & 7 & - & - & - & - & - & - & - & 2.98 & 1.23 & 0.736 & 6.32 & 4.02 & 4.52 \\
\hline N14 & 8 & + & - & + & + & - & - & + & 2.91 & 1.13 & -1.116 & 8.97 & 3.50 & 3.67 \\
\hline N16 & 9 & + & + & + & + & + & + & + & 2.91 & 1.12 & -0.214 & 6.93 & 3.50 & 3.58 \\
\hline N17 & 10 & 0 & 0 & 0 & 0 & 0 & 0 & 0 & 3.01 & 1.17 & -0.143 & 6.71 & 3.88 & 4.24 \\
\hline N9 & 11 & - & - & - & + & - & + & + & 2.98 & 1.17 & 0.473 & 5.97 & 4.05 & 4.26 \\
\hline N8 & 12 & + & + & + & - & + & - & - & 2.88 & 1.21 & -0.702 & 7.48 & 3.27 & 3.48 \\
\hline N4 & 13 & + & + & - & - & - & + & + & 3.24 & 1.14 & -0.303 & 7.62 & 3.98 & 4.38 \\
\hline N6 & 14 & + & - & + & - & - & + & - & 3.23 & 1.19 & -1.028 & 8.93 & 3.36 & 3.53 \\
\hline N18 & 15 & 0 & 0 & 0 & 0 & 0 & 0 & 0 & 3.01 & 1.18 & -0.130 & 6.61 & 3.86 & 3.95 \\
\hline N5 & 16 & - & - & + & - & + & + & + & 1.92 & 1.24 & -0.164 & 5.33 & 2.58 & 2.65 \\
\hline N15 & 17 & - & + & + & + & - & + & - & 3.00 & 1.13 & 0.961 & 5.89 & 4.16 & 4.48 \\
\hline N7 & 18 & - & + & + & - & - & - & + & 2.16 & 1.20 & -0.543 & 4.46 & 3.18 & 3.45 \\
\hline N10 & 19 & + & - & - & + & + & + & - & 4.59 & 1.13 & -0.551 & 11.26 & 5.64 & 5.78 \\
\hline
\end{tabular}

the mobile phase flow rate and the column temperature. The screened parameters and their corresponding levels are shown in Table 2.

The nineteen experiments presented in Table 3 were carried out according to the design of experiments that also includes three central point experiments for the determination of experimental error. These are experiments N17, N18 and N19. Six responses were measured for each experiment: the retention factor of $\mathrm{BKC} \mathrm{C12} \mathrm{homolog}$
$\left(\mathrm{k}_{\mathrm{C} 12}\right)$, tailing for $\mathrm{BKC} \mathrm{C12}$ homolog $\left(\mathrm{T}_{\mathrm{C} 12}\right)$, the retention difference between an unknown placebo peak (denoted as Unk P) and BKC C12 homolog $\left(\mathrm{Rs}_{\mathrm{P}, \mathrm{C} 12}\right)$, resolution between the active compound and BKC C12 homolog $\left(\mathrm{Rs}_{\mathrm{A}, \mathrm{C} 12}\right)$, resolution between BKC C12 and $\mathrm{C} 14$ homo$\operatorname{logs}\left(\mathrm{Rs}_{\mathrm{C} 12, \mathrm{C} 14}\right)$ and resolution between $\mathrm{BKC} \mathrm{C} 14$ and $\mathrm{C} 16$ homologs $\left(\mathrm{Rs}_{\mathrm{C} 14, \mathrm{Cl} 16}\right)$; see

Table 3 for the results. The retention difference between an unknown placebo peak and BKC C12 homolog

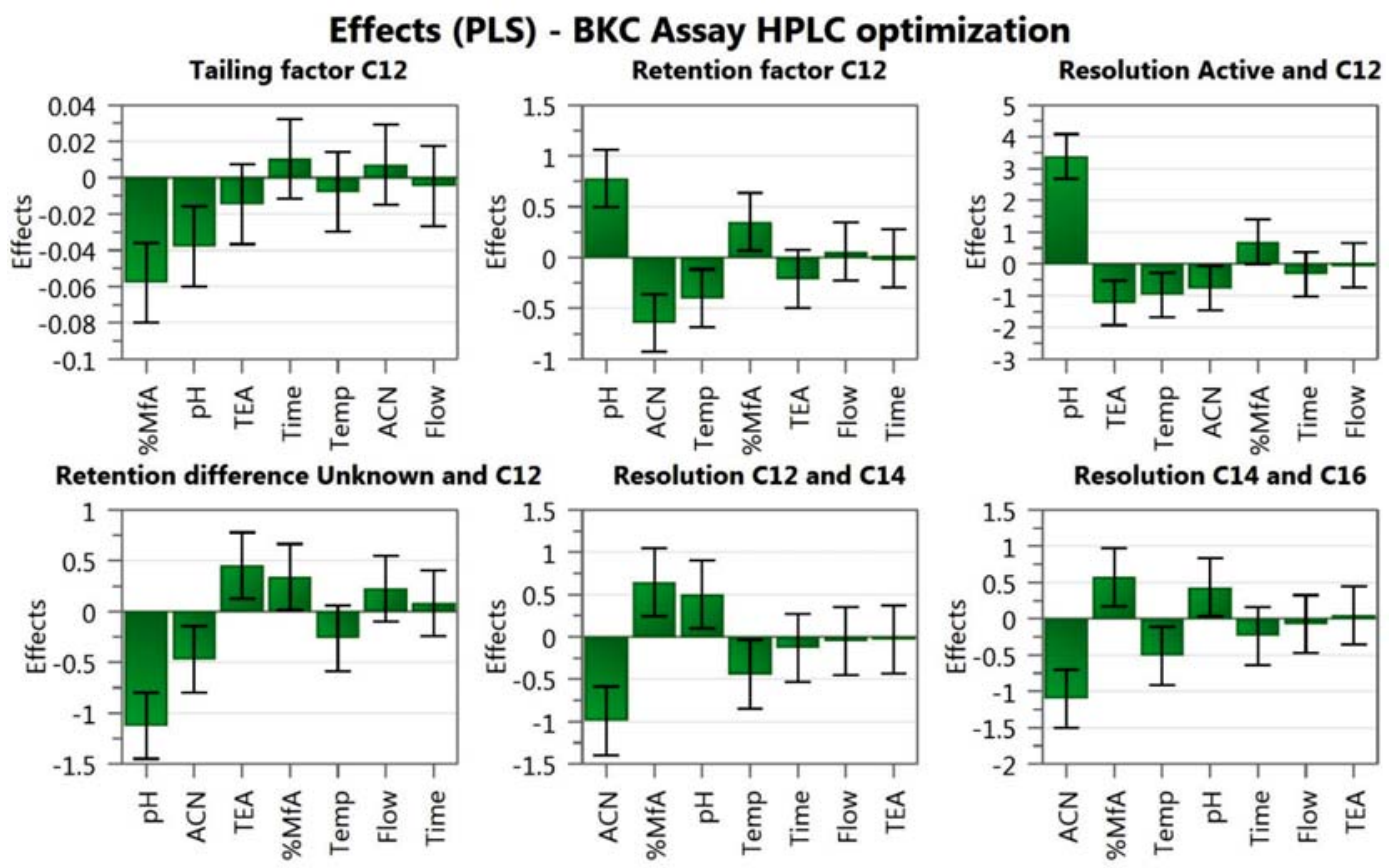

Figure 2. Main effects for all observed responses for HPLC method optimization for BKC assay determination. 

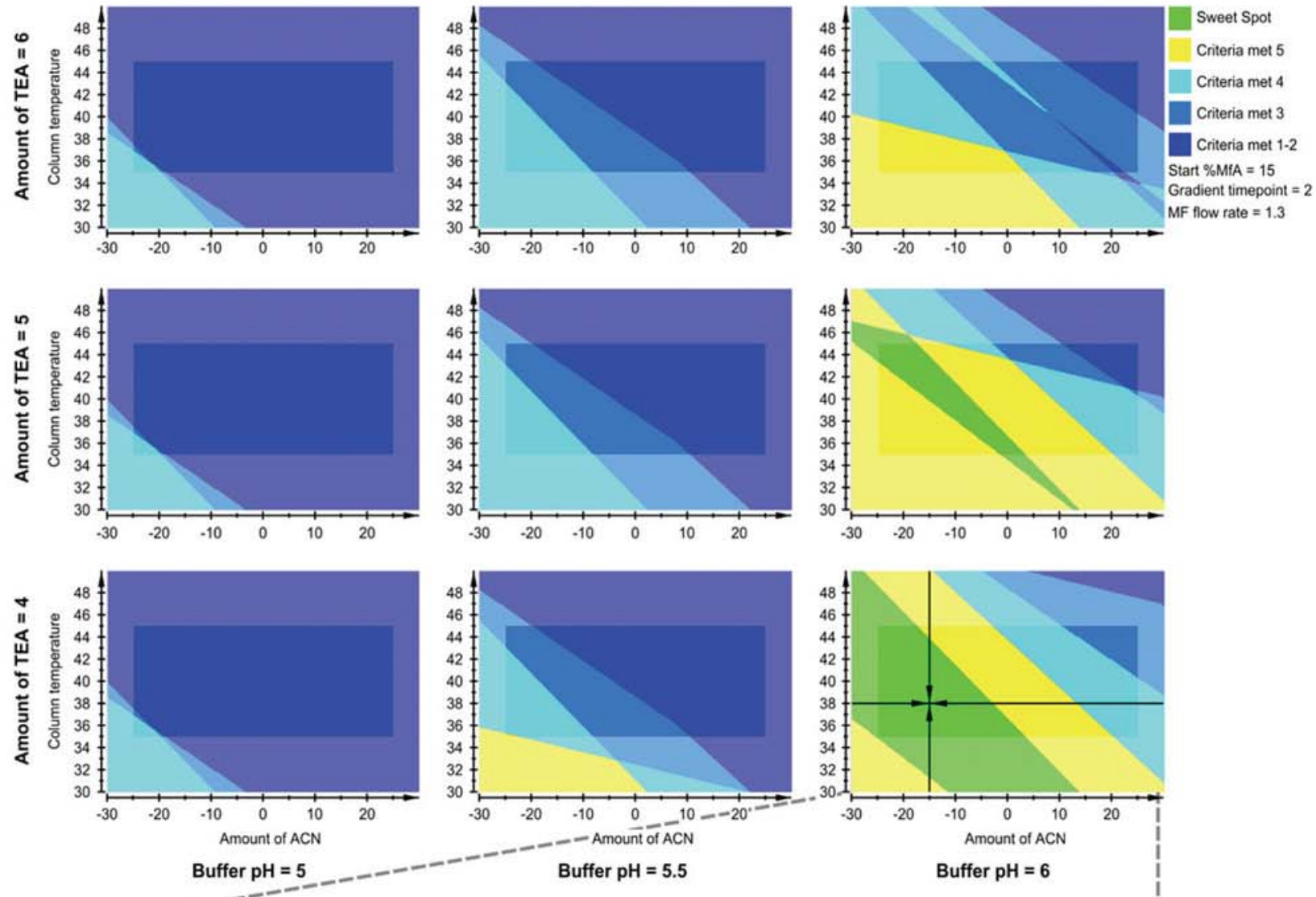

Buffer $\mathrm{pH}=5.5$

Buffer $\mathrm{pH}=6$

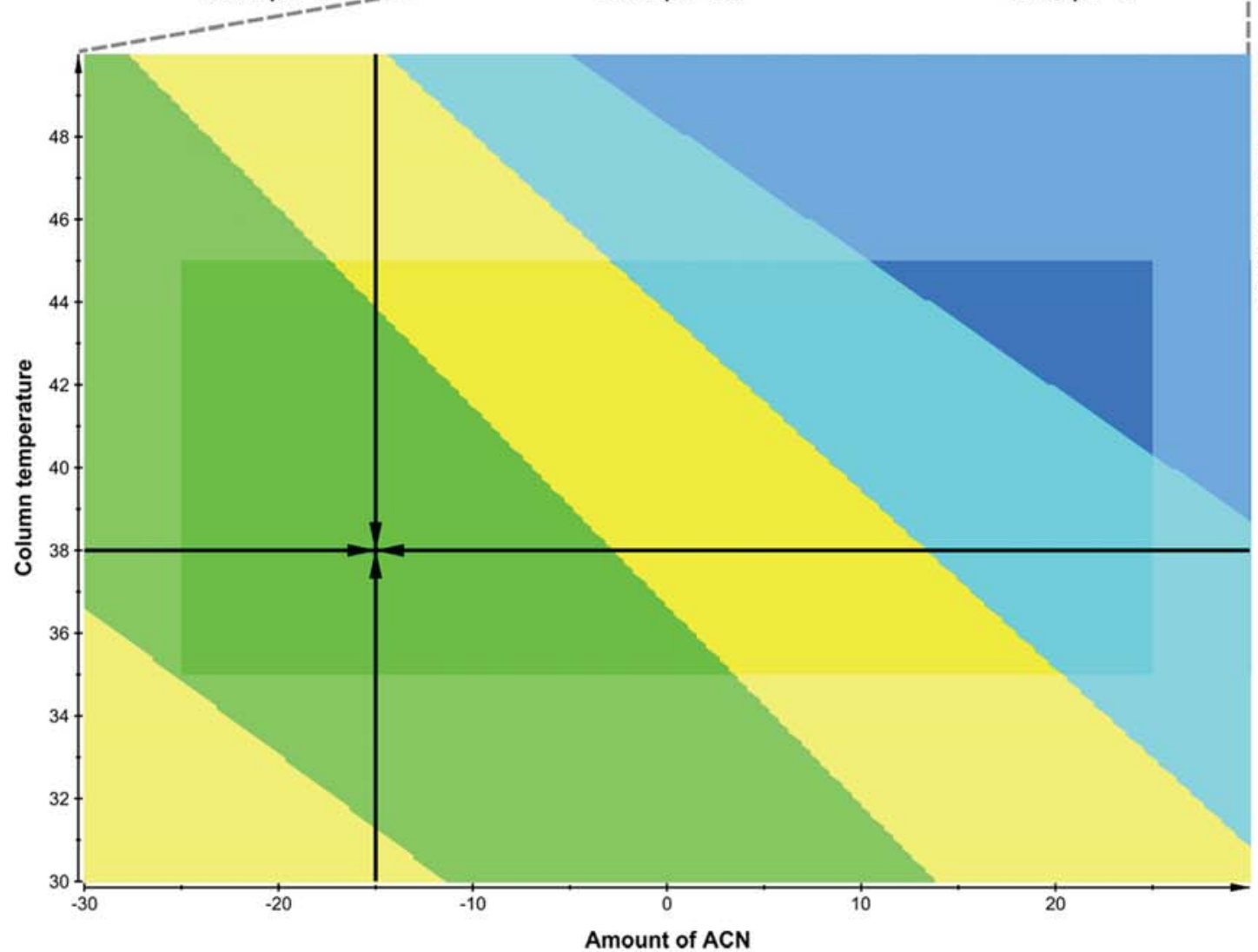

Figure 3. Sweet spot diagram for a PLS model of the analytical operational design region. The optimal chromatographic conditions proposed by MODDE are marked with a cross. 
has a negative value when the elution order of the two peaks is switched.

All collected data was processed with Umetrics MODDE 9.1 software. The Partial Least Squares (PLS) statistical model was computed and optimized for each observed response, while non-significant factors were excluded from the model. After detailed analysis the main significant factors for each response were identified using this model, as shown in Figure 2.

From Figure 2 it can be seen that the mobile phase $\mathrm{pH}$ has the most significant effect on the retention factor of $\mathrm{BKC} \mathrm{C12} \mathrm{homolog,} \mathrm{the} \mathrm{resolution} \mathrm{between} \mathrm{the} \mathrm{active} \mathrm{com-}$ pound and $\mathrm{C} 12$ homolog and the resolution between the interfering unknown peak and $\mathrm{C} 12$ homolog. A higher mobile phase $\mathrm{pH}$ leads to better resolution between the interfering peaks of the active and unknown compounds from BKC homolog peaks, but leads to higher retention times of BKC homologs. On the other hand the amount of ACN in the mobile phase particularly affects the resolution between the homologs of BKC. With a higher amount of $\mathrm{ACN}$, the resolution between BKC homologs is reduced mainly due to shorter retention times on the HPLC column.

The design space of the analytical method was modeled using a MODDE integrated sweet spot analysis tool. The optimal chromatographic conditions were predicted by setting the appropriate criteria for each observed response (Figure 3).

The design space model for all factors, in which three factors were fixed, is shown in the sweet spot diagram in Figure 3. The green area represents the part of the design space where all criteria for the observed responses were met; this is considered a sweet spot. The calculated sweet spot is marked with a black cross. The sweet spot prediction is in accordance with our conclusions based upon the significance of individual effects on observed responses. The optimal conditions are achieved with a mobile phase containing less ACN and with a higher $\mathrm{pH}$. The mobile phase flow rate and column temperature are reduced to help achieve the best separation, while the gradient time point does not have any significant effect.

Table 4. Statistical model prediction for responses at optimal chromatographic conditions and experimental results obtained in a confirmation run.

\begin{tabular}{lcccc}
\hline Factor & Predicted & Lower & Upper & Observed \\
\hline Retention factor C12 & 3.61 & 3.38 & 3.83 & 4.11 \\
Tailing C12 & 1.17 & 1.15 & 1.19 & 1.06 \\
Resolution A,C12 & 9.91 & 9.16 & 10.75 & 9.72 \\
Resolution P,C12 & -0.76 & -1.07 & -0.45 & -1.37 \\
Resolution C12,C14 & 4.38 & 4.03 & 4.78 & 4.76 \\
Resolution C14,C16 & 4.74 & 4.40 & 5.09 & 4.88 \\
\hline
\end{tabular}
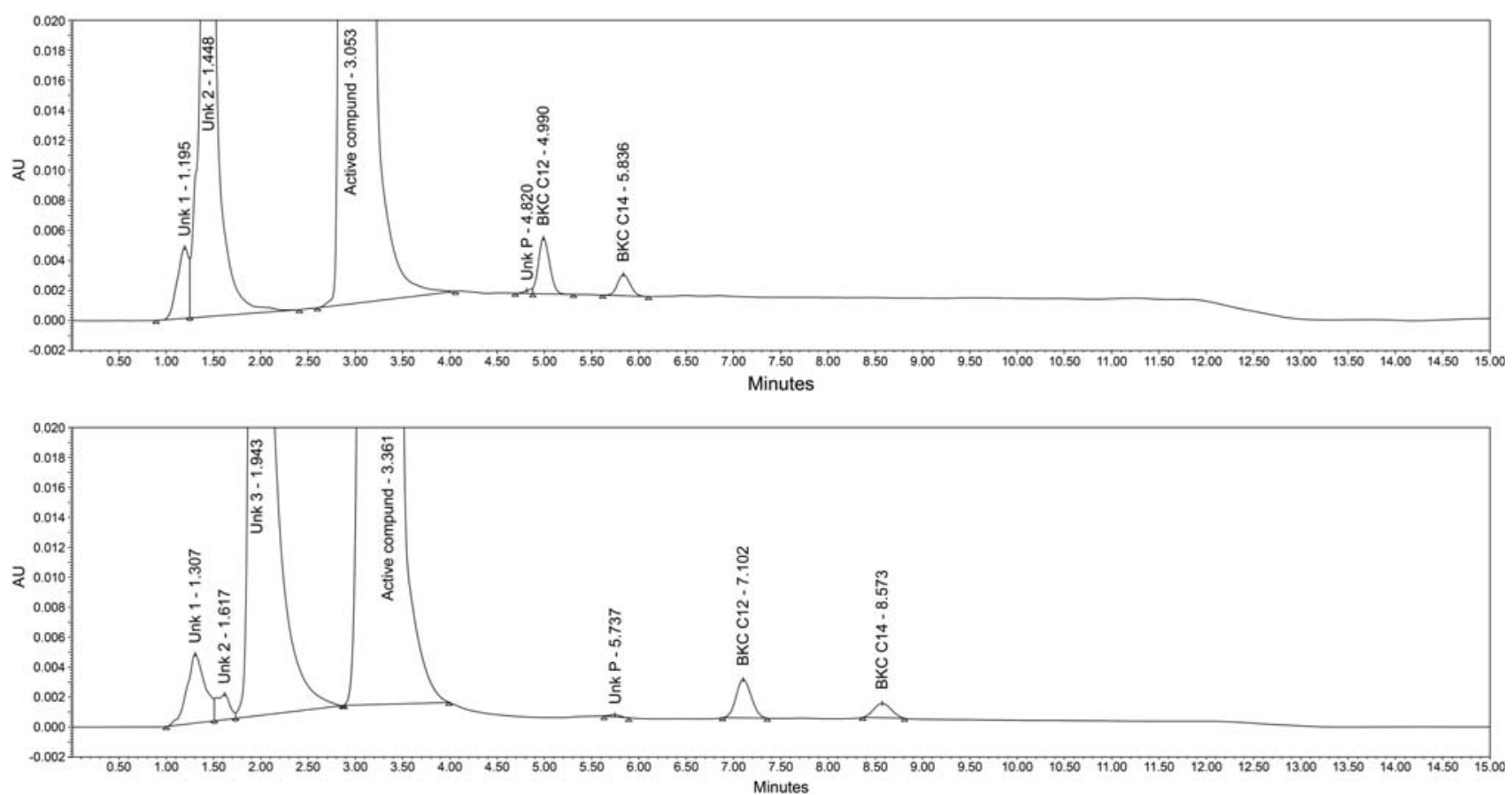

Figure 4. Chromatogram of sample analyzed with initial (top) and optimized (bottom) chromatographic conditions. The interfering placebo peak in the chromatograms is labelled as UnkP and benzalkonium chloride homologs as BKC C12 and BKC C14. 
Using the MODDE statistical model, a prediction of observed responses was made for each proposed optimal experimental condition. An experimental confirmation test, the results of which are summarized in Table 4, was performed to confirm the validity of the statistical model.

From Table 4 it can be seen that the observed responses are within the predicted confidence intervals. The resolution between the placebo peak and the BKC homo$\log \mathrm{C} 12$ peak (Resolution $\mathrm{P}, \mathrm{C}_{12}$ ) was even better than the prediction of the statistical model.

Chromatograms obtained with the initial method (Table 1) and with the optimized analytical method using the conditions calculated from the sweet spot analysis are shown in Figure 4. From this it can be seen that superior resolution between the active compound and the BKC homologs is achieved with the optimized method and additionally, an interfering placebo peak (in Figure 4 denoted as Unk P) is also separated from the BKC homolog C12. The unknown peaks at the beginning of the chromatograms in Figure 4, labelled as Unk 1, Unk 2 and Unk 3, are responses arising from the placebo and solvent and do not interfere with the assay determination of BKC.

\section{2. Sample Preparation Optimization}

Another fractional factorial design was used to optimize the sample preparation step of the analytical method. Five different factors, shown in Table 5, were identified in the sample preparation step: the type of the pipette used for sample dilution, the weight of the sample, the amount of water in the solvent used for diluting, the amount of
$\mathrm{H}_{3} \mathrm{PO}_{4}$ added to the sample solution and the shaking time. Eleven randomized experiments were performed according to a fractional factorial experimental design, including three initial point experiments as shown in Table 6. Three responses were measured for each experiment: assay of BKC in the sample, tailing for BKC homolog C12 $\left(\mathrm{T}_{\mathrm{C} 12}\right)$ and tailing for $\mathrm{BKC}$ homolog $\mathrm{C} 14\left(\mathrm{~T}_{\mathrm{C} 14}\right)$.

All samples were analyzed using the optimized analytical method. The results are presented in Table 6 .

A PLS model was constructed and the optimal sample preparation conditions were identified. The effects of the individual factors on the observed responses after the model optimization are presented in Figure 5.

From the model, it is evident that both the solvent type and sample weight have significant effects on the assay determination of BKC in the samples. Due to the insolubility of the active compound in water, better results were obtained using a solvent mixture of $\mathrm{H}_{2} \mathrm{O}: \mathrm{ACN}=75$ : 25 , as opposed to pure $\mathrm{ACN}$, as the concentration of the active compound in the final sample solution was reduced. As use of a higher sample weight results in an increased concentration of BKC in the final sample solution, e the responses under the BKC peaks were higher and the method precision was better. The pipette type, shaking time and the amount of $\mathrm{H}_{3} \mathrm{PO}_{4}$ added to the sample solution did not have any significant effect on the observed responses.

From the chromatograms presented in Figure 6, it can be seen that a smaller active compound peak, due to lower concentration, was achieved as it is practically insoluble in water. In contrast, the peaks of the BKC homologs have higher areas due to the doubled sample mass.

Table 5. Factors used in the experimental design for sample preparation optimization.

\begin{tabular}{|c|c|c|c|c|c|}
\hline $\begin{array}{l}\text { Factor name } \\
\text { (f1) Pipette type }\end{array}$ & $\begin{array}{l}\text { Abbr. } \\
\text { Pip }\end{array}$ & $\begin{array}{c}\text { Settings } \\
\text { HDPE, Glass }\end{array}$ & $\begin{array}{c}\text { Level - } \\
\text { HDPE }\end{array}$ & $\begin{array}{c}\text { Level + } \\
\text { Glass }\end{array}$ & $\begin{array}{c}\text { Level } 0 \\
\text { HDPE }\end{array}$ \\
\hline (f2) Sample weight & W & 0.2 to $0.4 \mathrm{~g} / \mathrm{mL}$ & $0.2 \mathrm{~g} / \mathrm{mL}$ & $0.4 \mathrm{~g} / \mathrm{mL}$ & $0.2 \mathrm{~g} / \mathrm{mL}$ \\
\hline (f3) Solvent type & Sol & $0 \% \mathrm{H}_{2} \mathrm{O}, 75 \% \mathrm{H}_{2} \mathrm{O}$ & $0 \% \mathrm{H}_{2} \mathrm{O}$ & $75 \% \mathrm{H}_{2} \mathrm{O}$ & $0 \% \mathrm{H}_{2} \mathrm{O}$ \\
\hline (f4) Amount of $\mathrm{H}_{3} \mathrm{PO}_{4}$ & Acid & 30 to $50 \mu \mathrm{L}$ & $30 \mu \mathrm{L}$ & $50 \mu \mathrm{L}$ & $40 \mu \mathrm{L}$ \\
\hline (f5) Shaking time & Time & 10 to $20 \mathrm{~min}$ & $10 \mathrm{~min}$ & $20 \mathrm{~min}$ & $15 \mathrm{~min}$ \\
\hline
\end{tabular}

Table 6. Randomized $2^{7-3}$ fractional factorial design used for sample preparation optimization with results for observed responses.

\begin{tabular}{lcccccccc}
\hline $\begin{array}{l}\text { Exp } \\
\text { No }\end{array}$ & $\begin{array}{r}\text { Run } \\
\text { Order }\end{array}$ & $\mathbf{f 1}$ & $\mathbf{f 2}$ & $\mathbf{f 3}$ & $\mathbf{f 4}$ & $\mathbf{f 5}$ & \multicolumn{2}{c}{ Responses } \\
\hline N6 & 1 & - & - & + & - & + & 93.33 & 1.04 \\
N2 & 2 & - & - & - & - & - & 96.15 & 1.14 \\
N3 & 3 & + & + & - & - & + & 98.36 & 1.12 \\
N1 & 4 & + & - & - & + & + & 94.21 & 1.01 \\
N5 & 5 & + & - & + & + & - & 90.73 & 0.79 \\
N7 & 6 & + & + & + & - & - & 94.23 & 1.07 \\
N10 & 7 & 0 & 0 & 0 & 0 & 0 & 95.73 & 1.09 \\
N9 & 8 & 0 & 0 & 0 & 0 & 0 & 95.00 & 1.14 \\
N11 & 9 & 0 & 0 & 0 & 0 & 0 & 94.33 & 1.14 \\
N4 & 10 & - & + & - & + & - & 98.24 & 1.03 \\
N8 & 11 & - & + & + & + & + & 93.53 & 1.06 \\
\hline
\end{tabular}




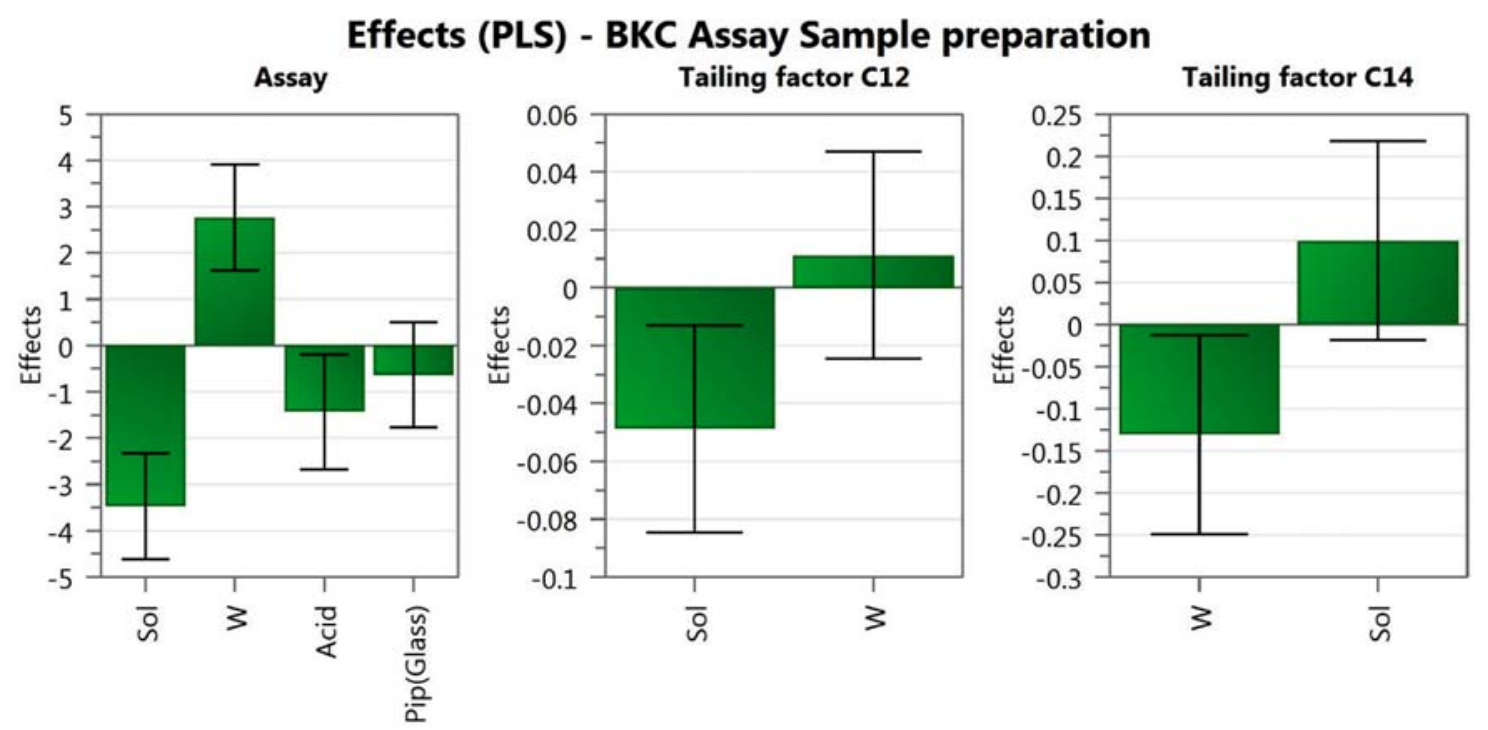

Figure 5. The main effects after PLS model optimization for all observed responses for sample preparation optimization. Non-significant factors are excluded from the model.

For optimal sample preparation, the sample weight was increased from $5 \mathrm{~g}$ to $10 \mathrm{~g}$ of suspension sample, and the solvent was changed from pure $\mathrm{ACN}$ to a mixture of $\mathrm{H}_{2} \mathrm{O}: \mathrm{ACN}=75: 25$. The higher sample weight resulted in higher area of $\mathrm{BKC}$ homologs and therefore better repeatability (precision) of the analytical results. The change of the solvent to a $75 \%$ water mixture resulted in elimination of the active compound peak due to its poor solubility in water.
The chromatograms obtained with the initial sample preparation and the optimal sample preparation are shown in Figure 6. It can be clearly seen that the peak of the active compound is reduced to a minimum, while the peaks of the BKC homologs are twice as high due to the higher concentration of BKC in the sample. Improved precision of the method, which was also confirmed during the Method validation presented in section 3.3.3, was achieved in this way.
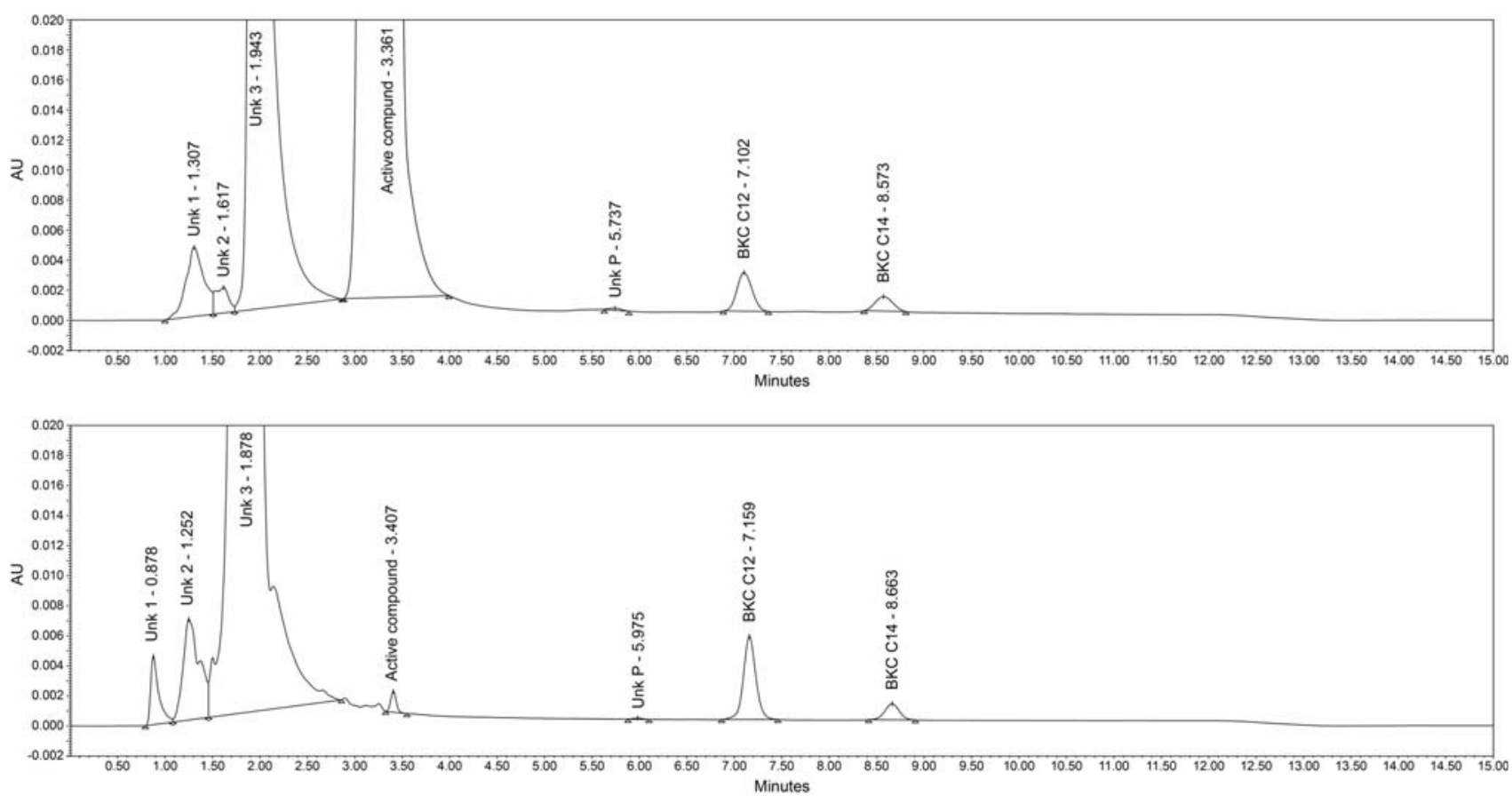

Figure 6. Chromatograms obtained with the initial sample preparation (top) and the optimized sample preparation (bottom) analyzed by the optimized HPLC method. The interfering placebo peak in the chromatograms is labelled as UnkP and benzalkonium chloride homologs as BKC C12 and BKC C14. 


\section{3. Analytical Method Validation}

The optimized analytical method was validated for linearity, working range, precision and accuracy for assay of benzalkonium chloride in nasal spray formulations.

\section{3. 1. Linearity and Working Range}

The linearity of the proposed analytical method was verified in the concentration range $15-120 \mu \mathrm{g} / \mathrm{mL}$ of BKC. The stock standard solution was prepared in three replicates, each with a concentration of approximately $1.5 \mathrm{mg} / \mathrm{mL}$. Each replicate was then diluted appropriately to obtain solutions of benzalkonium chloride with concentrations in the range $15-120 \mu \mathrm{g} / \mathrm{mL}$. The results of the calibration curves are presented in Table 7.

The high correlation coefficient values $(>0.9999)$ demonstrate the good linearity of the proposed method in the concentration range tested.

\section{3. 2. Precision}

The precision of the proposed method was checked with five replicate injections of a standard solution of benzalkonium chloride at the target concentration $(60 \mu \mathrm{g} / \mathrm{mL})$. The obtained results gave an intra-day RSD of $0.64 \%$. The inter-day precision was checked by three replicate injections of standard solution on different days. The obtained RSD of all injections was $0.77 \%$. The results indicate sufficient precision of the optimized HPLC method.

\section{3. 3. Accuracy}

The accuracy of the method was checked by spiking a placebo suspension (without preservative) with a stock standard solution of benzalkonium chloride. The accuracy was determined by analyzing the aforementioned standard solutions at five different concentrations levels ranging

Table 7. Calibration curve data for BKC by optimized HPLC method in concentration range $15-120 \mu \mathrm{g} / \mathrm{mL}$.

\begin{tabular}{|c|c|c|c|c|c|c|c|c|}
\hline \multirow[b]{2}{*}{$\begin{array}{l}\text { Calibration } \\
\text { level }\end{array}$} & \multicolumn{2}{|c|}{ Replicate 1} & \multicolumn{2}{|c|}{ Replicate 2} & \multicolumn{2}{|c|}{ Replicate 3} & \multicolumn{2}{|c|}{ Average calibration curve } \\
\hline & $\begin{array}{l}\text { Amount } \\
\text { mg/mL }\end{array}$ & $\begin{array}{l}\text { Response } \\
{\left[\mu V^{*} \text { sec }\right]}\end{array}$ & $\begin{array}{l}\text { Amount } \\
\mathrm{mg} / \mathrm{mL}\end{array}$ & $\begin{array}{l}\text { Response } \\
{\left[\mu V^{*} \text { sec }\right]}\end{array}$ & $\begin{array}{l}\text { Amount } \\
\text { mg/mL }\end{array}$ & $\begin{array}{l}\text { Response } \\
{\left[\mu V^{*} \text { sec }\right]}\end{array}$ & $\begin{array}{c}\text { Amount } \\
\text { mg/mL }\end{array}$ & $\begin{array}{l}\text { Response } \\
{\left[\mu V^{*} \text { sec }\right]}\end{array}$ \\
\hline 1 & 0.01500 & 20759.83 & 0.01501 & 21278.76 & 0.01501 & 21151.04 & 0.01501 & 21063.21 \\
\hline 2 & 0.03000 & 42902.06 & 0.03002 & 42950.15 & 0.03002 & 43149.95 & 0.03001 & 43000.72 \\
\hline 3 & 0.04501 & 64482.73 & 0.04503 & 65028.95 & 0.04503 & 65161.73 & 0.04502 & 64891.14 \\
\hline 4 & 0.06001 & 87298.04 & 0.06003 & 87619.73 & 0.06004 & 86908.82 & 0.06003 & 87275.53 \\
\hline 5 & 0.09001 & 132103.09 & 0.09005 & 130897.06 & 0.09006 & 131682.36 & 0.09004 & 131560.83 \\
\hline 6 & 0.12002 & 176780.25 & 0.12007 & 176586.27 & 0.12008 & 176621.18 & 0.12005 & 176662.57 \\
\hline Slope & & 1487541.7 & & 1476355.0 & & 1479338.7 & & 1481077.6 \\
\hline Intercept & & -1878.0 & & -1238.7 & & -1370.0 & & -1495.6 \\
\hline $\mathbf{R}^{2}$ & & 0.99997 & & 0.99993 & & 0.99997 & & 0.99997 \\
\hline
\end{tabular}

Table 8. Results of recovery experiments at five concentration levels of BKC, obtained with optimized HPLC method.

\begin{tabular}{|c|c|c|c|c|c|c|c|c|c|}
\hline \multicolumn{2}{|c|}{ Spiked sample level } & \multirow{2}{*}{$\begin{array}{c}\begin{array}{c}\text { Added } \\
{[\mathrm{mg} / \mathrm{mL}]}\end{array} \\
0.030020\end{array}$} & \multirow{2}{*}{$\begin{array}{c}\begin{array}{c}\text { Found } \\
{[\mathrm{mg} / \mathbf{m L}]}\end{array} \\
0.029208\end{array}$} & \multirow{2}{*}{$\begin{array}{c}\begin{array}{c}\text { Recovery } \\
\text { [\%] }\end{array} \\
97.29\end{array}$} & \multirow{2}{*}{$\begin{array}{c}\text { Average }(\mathbf{n}=\mathbf{3}) \\
{[\%]} \\
97.47\end{array}$} & \multirow{2}{*}{$\begin{array}{c}\text { SD } \\
0.43\end{array}$} & \multirow{2}{*}{$\begin{array}{l}\text { RSD } \\
0.44\end{array}$} & \multirow{2}{*}{$\begin{array}{c}\begin{array}{c}\text { CI min } \\
\text { [\%] }\end{array} \\
95.61\end{array}$} & \multirow{2}{*}{$\begin{array}{c}\text { CI max } \\
\text { [\%] }\end{array}$} \\
\hline & Replicate 1 & & & & & & & & \\
\hline \multirow[t]{3}{*}{$50 \%$} & Replicate 2 & 0.030035 & 0.029182 & 97.16 & & & & & \\
\hline & Replicate 3 & 0.030020 & 0.029410 & 97.97 & & & & & \\
\hline & Replicate 1 & 0.045030 & 0.044541 & 98.91 & 99.17 & 0.63 & 0.64 & 96.45 & 101.90 \\
\hline \multirow[t]{2}{*}{$75 \%$} & Replicate 2 & 0.045053 & 0.044471 & 98.71 & & & & & \\
\hline & Replicate 3 & 0.045031 & 0.044982 & 99.89 & & & & & \\
\hline & Replicate 1 & 0.060040 & 0.059398 & 98.93 & 98.73 & 0.30 & 0.30 & 97.44 & 100.03 \\
\hline \multirow[t]{3}{*}{$100 \%$} & Replicate 2 & 0.060070 & 0.059100 & 98.38 & & & & & \\
\hline & Replicate 3 & 0.060041 & 0.059367 & 98.88 & & & & & \\
\hline & Replicate 1 & 0.075050 & 0.073840 & 98.39 & 98.48 & 0.54 & 0.54 & 96.18 & 100.79 \\
\hline \multirow[t]{3}{*}{$125 \%$} & Replicate 2 & 0.075088 & 0.073590 & 98.00 & & & & & \\
\hline & Replicate 3 & 0.075051 & 0.074347 & 99.06 & & & & & \\
\hline & Replicate 1 & 0.090060 & 0.088820 & 98.62 & 98.46 & 0.84 & 0.86 & 94.83 & 102.09 \\
\hline \multirow[t]{5}{*}{$150 \%$} & Replicate 2 & 0.090106 & 0.087896 & 97.55 & & & & & \\
\hline & Replicate 3 & 0.090061 & 0.089349 & 99.21 & & & & & \\
\hline & & \multicolumn{2}{|c|}{ Total Average $(\mathrm{n}=15)$} & 98.46 & & & & & \\
\hline & & & SD & 0.76 & & & & & \\
\hline & & & RSD & 0.77 & & & & & \\
\hline
\end{tabular}


from $30-90 \mu \mathrm{g} / \mathrm{mL}$. All samples were prepared in three replicates using the optimized sample preparation procedure and analyzed with the optimized HPLC method. The recovery factor was calculated; the obtained results are presented in Table 8.

\section{3. 4. Sample Analysis}

In order to demonstrate the superior precision and accuracy of the optimized analytical method, two different types of samples were analyzed with both the initial analytical method and the proposed optimized analytical method. One of the samples was a nasal spray solution and the other a nasal spray suspension, with both containing an active compound from the group of locally-acting pharmaceutical compounds.
Statistical models of analytical method operational region can be set using statistical evaluation of the results obtained from the experimental designs. This study shows that such models of analytical method operational region can provide an improved perspective and knowledge of the analytical procedure.

By using a systematic approach for optimization of the chromatographic conditions and the sample preparation step of the initial HPLC method, only 30 experiments were performed in order to reach the optimal method conditions. A PLS model was successfully introduced to screen the main effects of factors that have a significant effect on the responses measured. Evaluation of several validation parameters showed that the predictions of the model were satisfactory and gave us a good understanding of the analytical method operational region.

Table 9. Comparison of the analysis results of two different types of samples analyzed using the initial procedure and the proposed optimized analytical method procedure. Average assay \pm SD (RSD) of the individual measurements are presented.

\begin{tabular}{lcc}
\hline \multirow{2}{*}{ Formulation } & $\begin{array}{c}\text { Initial method } \\
\text { Assay }\end{array}$ & $\begin{array}{c}\text { Optimized method } \\
\text { Assay }\end{array}$ \\
& $\begin{array}{c}\text { Average } \pm \text { SD (RSD) } \\
\text { Nasal solution formulation }\end{array}$ & $\begin{array}{c}\mathbf{9 5 . 4} \pm \mathbf{0 . 2}(\mathbf{0 . 2}) \\
\text { Average } \pm \text { SD (RSD) }\end{array}$ \\
\hline \multirow{2}{*}{ Nasal suspension formulation } & $95.2,95.4,95.6$ & $\mathbf{9 2 . 3} \pm \mathbf{0 . 2}(\mathbf{0 . 2})$ \\
& $\mathbf{1 0 1 . 9} \pm \mathbf{0 . 4}(\mathbf{0 . 4})$ & $92.1,92.3,92.4$ \\
\hline
\end{tabular}

From Table 9 it can be seen that the results obtained with the optimized method for BKC assay in both nasal spray formulations are lower as the interfering placebo peak was separated from BKC C12 homolog. The variability of the results is comparable or lower as in case of nasal suspension formulation, where the precision of the results was reduced to RSD $0.2 \%$.

\section{Conclusions}

Using a traditional one-factor-at-a-time (OFAT) approach, 128 experiments would be needed to cover the same analytical method operational region for chromatographic conditions optimization and an additional 32 experiments for optimization of the sample preparation step. In the presented study, the use of experimental designs significantly reduced the number of required experiments, while the information attained about the analytical method operational region was still sufficient to determine the significant effects of tested factors and even their interactions, which would not be possible with the OFAT approach.

Such a systematic approach is therefore recommended in the case of optimization, where screening of a large number of factors is necessary to isolate factors with significant effects on the observed responses.
The selection of optimal solvent used for sample preparation allowed us to reduce the concentration of the active compound in the sample solutions and with a higher sample weight achieve a higher concentration of the BKC homologs. The result of the optimization was a large reduction of the active compound peak area while the area of BKC homolog peaks was almost doubled. The optimization of HPLC chromatography conditions resulted in improved resolution between the active compound peak and the BKC homolog peaks and the separation of placebo peaks and $\mathrm{BKC}$ homolog peaks.

The analytical method was validated according to ICHQ2R1 guidelines. ${ }^{26}$ The method was successfully applied for determination of the assay of BKC in two different nasal spray formulations. With optimization of the sample preparation step, different types of samples (nasal spray solutions and nasal spray suspensions) can also be analyzed with a single robust method instead of using two different analytical procedures. The enhanced performance of the optimized sample preparation step and chromatographic method were confirmed with the analysis of two different types of samples containing different locally acting active pharmaceutical compounds. For both samples, more accurate and precise results were obtained with the proposed optimized analytical method. 


\section{References}

1. ICH Guideline: Pharmaceutical Development Q8(R2), CHMP/ICH/167068/04.

2. Pharmaceutical cGMPs for the 21st Century - A Risk-Based Approach, U.S. Food and Drug Administration (FDA).

3. S. Bohanec, T. Rozman Peterka, P. Blažič, R. Jurečič, J. Grmaš, A. Krivec, J. Zakrajšek, Acta Chim. Slov. 2010, 57, 895-903.

4. P. Petelin, M. Homar, A. Bajc, J. Kerč, S. Bohanec, Acta Chim. Slov. 2012, 59, 156-162.

5. F. G. Vogt, A. S. Kord, J. Pharm. Sci. 2011, 100, 797-812. http://dx.doi.org/10.1002/jps.22325

6. J. Ermer, P. J. Borman, J. Carolan, P. Faulkner, C. Finkler, O. Grosche, M. Hanna-Brown, J. Hoffmann, I. Gill, A. Lenhart, P. W. Nethercote, A. Rignall, T. Sokoliess, G. Wegener, M. Pohl, Pharmind 2010, 72, 256-264.

7. P. Borman, P. Nethercote, M. Chatfield, D. Thompson, K. Truman, Pharm. Technol. 2007, 31, 142-152.

8. P. Borman, J. Roberts, C. Jones, M. Hanna-Brown, R. Szucs, S. Bale, Sep. Sci. 2010, 2, 2-8.

9. M. Schweitzer, M. Pohl, M. Hanna-Brown, P. Nethercote, P. Borman, G. Hansen, K. Smith, J. Larew, Pharm. Technol. 2010, 34, 52-59.

10. T. W. Graul, K. L. Barnett, S. J. Bale, I. Gill, M. HannaBrown, in: D.J. am Ende (Ed.): Chemical Engineering in the Pharmaceutical Industry: R\&D to Manufacturing, Wiley, Hoboken, NJ, US, 2011, pp. 545-562.

11. M. Moder, S. Bohanec, J. Zupan, Acta Chim. Slov. 1997, 44, 181-196.

12. S. Karmarkar, R. Garber, Y. Genchanok, S. George, X. Yang, R. Hammond, J. Chromatogr. Sci. 2011, 49, 439-446. http://dx.doi.org/10.1093/chrsci/49.6.439

13. D. Awotwe-Otoo, C. Agarabi, P. J. Faustino, M. J. Habib, S. Lee, M. A. Khan, R. B. Shah, J. Pharm. Biomed. Anal. 2012, 62, 61-67. http://dx.doi.org/10.1016/j.jpba.2012.01.002

14. M. Hanna-Brown, P. Borman, S. Bale, R. Szucs, J. Roberts, C. Jones, Sep. Sci. 2010, 2, 12-20.

15. L. Zhou, J. M. Socha, F. G. Vogt, S. Chen, A. S. Kord, Am. Pharm. Rev. 2010, 74-84.

16. B. Marple, P. Roland, M. Benninger, Otolaryngol. Head Neck Surg. 2004, 130, 131-141. http://dx.doi.org/10.1016/j.otohns.2003.07.005

17. R. C. Rowe, P. J. Sheskey, W. G. Cook, M. E. Fenton: Handbook of Pharmaceutical Excipients, Pharmaceutical Press, London, 6th ed., 2009.

18. N. R. Barbosa, Y. P. Cid, F. L. H. de Carvalho, A. S. Ferreira, J. A. Silva, Lat. Am. J. Pharm. 2009, 28, 288-292.

19. J. Dudkiewicz-Wilczynska, J. Tautt, I. Roman, J. Pharm. Biomed. Anal. 2004, 34, 909-920. http://dx.doi.org/10.1016/j.jpba.2003.09.001

20. G. Santoni, A. Medica, P. Gratteri, S. Furlanetto, S. Pinzauti, Farmaco 1994, 49, 751-754.

21. H. K. Trivedi, M. C. Patel, E-J. Chem. 2010, 7, 1514-1522.

22. Y. H. Hou, C. Y. Wu, W. H. Ding, J. Chromatogr. A 2002, 976, 207-213. http://dx.doi.org/10.1016/S0021-9673(02)00943-3

23. B. V. Para, O. Nunez, E. Moyano, M. T. Galceran, Electrophoresis 2006, 27, 2225-2232. http://dx.doi.org/10.1002/elps.200500716

24. M. J. O'Neil: The Merck Index: An Encyclopedia of Chemicals, Drugs, and Biologicals, Merck, Whitehouse Station, NJ, US, 14th ed., 2006.

25. L. Eriksson, E. Johansson, N. Kettaneh-Wold, C. Wikstrom, S. Wold: Design of Experiments - Principles and Applications, Umetrics AB, Umea, Sweden, 3rd ed., 459, 2008.

26. ICH Guideline: Validation of Analytical Procedures: Text and Methodology Q2(R1), CPMP/ICH/381/95.

\section{Povzetek}

S pomočjo dveh delnih faktorskih načrtov smo ovrednotili učinek sedmih različnih kromatografskih parametrov in petih parametrov priprave vzorca $v$ metodi tekočinske kromatografije visoke ločljivosti (HPLC) za določanje vsebnosti benzalkonijevega klorida (BKC) v farmacevtskih pripravkih za aplikacijo na nosno sluznico. S pomočjo programskega paketa Umetrics Modde smo modelirali delovno območje analizne metode in napovedali optimalne pogoje za izvedbo analize. Optimalne pogoje kromatografske ločbe smo dosegli z uporabo kolone Luna CN $(150 \times 4.6 \mathrm{~mm}, 3 \mu \mathrm{m})$. Rezultati so pokazali, da so $\mathrm{pH}$ mobilne faze, delež acetonitrila v mobilni fazi in temperatura kolone najpomembnejši dejavniki za dosego dobre ločbe BKC homologov od motečih vrhov placeba. Pri pripravi vzorca je najpomembnejši dejavnik uporaba vodne raztopine za raztapljanje vzorcev, saj s tem zmanjšamo odziv aktivne učinkovine in posledično povečamo selektivnost. Optimizirano metodo smo validirali, pri čemer smo ovrednotili njeno linearnost, točnost in natančnost.

Uporaba metode statističnega načrtovanja poskusov nam omogoča, da z najmanjšim možnim številom izvedenih poskusov dobimo kar največ informacij o delovnem območju. Takšni načrti so ekonomičen način za vrednotenje različnih dejavnikov in njihovih interakcij. 